\title{
A seleção natural como narrativa sobre o grande divisor, a biossemiótica e as etnografias das pessoas humanas e não humanas
}

Gláucia Silva ${ }^{1}$

\section{Resumo}

Proponho uma leitura do neodarwinismo a partir de trabalhos de cientistas que pesquisam sobre o efeito de mutações não aleatórias (também chamadas dirigidas, interpretativas ou epigenéticas) e sobre a biossemiótica de Kalevi Kull, sempre no intuito de evidenciar a existência de visões diferentes da hegemônica. Discuto as críticas formuladas por Tim Ingold à biologia contemporânea e sua alternativa às metáforas dos geneticistas, afirmando que as considero fiéis à teoria, que é o que deve ser criticado. Finalmente, aponto que há, em alguma medida, convergência entre alguns biólogos e antropólogos, na percepção dos seres vivos como "pessoas", dotados de autoconsciência, e de uma Umwelt, tal como formulada por Jakob Uexküll. Sob a influência da crítica ao Grande Divisor, o perspectivismo e a etnografia multiespécie evidenciam, na antropologia, formas inéditas de lidar com os não humanos.

\section{Palavras-chave}

Antropologia da Ciência. Etnografia Multiespécie. Biossemiótica.

\begin{abstract}
I propose a reading of the Neo-Darwinism theory based on the works of scientists who research the effects of non-random mutations (also called directed, interpretative or epigenetic mutation) and Kalevi Kull's biosemiotics, always with the purpose of proving the existence of different views regarding hegemony. I also discuss Tim Ingold's criticisms regarding contemporary biology and his alternative to geneticists' metaphors, stating that I consider them to be true to theory, which is what should be criticized. Finally, I point out that there is, to some extent, a convergence between some biologists and anthropologists, in the perception of living beings as "people", endowed with selfawareness, and of an Umwelt, as formulated by Jakob von Uexküll. Under the influence of the criticism regarding the Great Divide, perspectivism and multispecies ethnography show, in anthropology, unprecedented ways of dealing with non-humans beings.
\end{abstract}

\section{Keywords}

Anthropology of Science. Multispecies Ethnography. Biosemiotics.

\footnotetext{
${ }^{1}$ Professora titular do Departamento de Antropologia da UFF. E-mail: glaucia.o.silva@gmail.com.
} 


\section{Introdução}

Em trabalho anterior, sustentei que a ideia de seleção natural como princípio explicativo da evolução das espécies tem permanecido como paradigma das ciências biológicas, sobretudo por ter caráter quimérico (SILVA, 2017), chancelado pelo determinismo genético. A seleção natural é uma teoria bipartida: de um lado, um organismo sofre uma mudança aleatória que, se for positiva, perdurará, podendo ocasionar a modificação daquela espécie; por outro lado, um "meio ambiente" (ou "natureza", no dizer de Darwin), considerado "a" instância que, atuando como um demiurgo, selecionará os mutantes adaptados.

A minha ideia, já exposta naquela ocasião (SILVA, 2017), de que o conceito de seleção natural pode ser relativizado como um princípio evolutivo aplicável de forma universal, se apoia em novas concepções sobre "mutação" como evento estritamente aleatório, que foi a pedra angular da cientificidade de que se revestiu o darwinismo por oposição ao lamarckismo. O princípio darwiniano selecionista vem sustentando que a base da evolução é aleatória. Entretanto, como já foi tratado anteriormente (SILVA; DUARTE, 2016), de algumas décadas para cá, cientistas mostraram que há modificações não aleatórias, isto é, induzidas pelo meio e reversíveis, como é o caso das mutações epigenéticas. Jablonka e Lamb (2010), Nicolosi e Ruivenkamp (2012), Kull (KULL et al., 2004, 2009; KULL, 2014) são biólogos que atribuem grande importância evolutiva às "mutações epigenéticas" e querem uma revisão do princípio selecionista.

A constatação da existência das mutações epigenéticas pode significar uma reviravolta teórica interna ao campo da biologia que, permanecendo hegemonicamente fiel aos princípios da seleção natural e ao determinismo genético, passa a exigir grande esforço para que as consequências dessas constatações mais recentes ganhem o reconhecimento por parte da mainstream, fortemente racionalista e mecanicista. Não que as mutações epigenéticas levem os cientistas necessariamente para longe do racionalismo ou mecanicismo, mas o conhecimento a respeito desse tipo de alteração no funcionamento dos genes pode questionar a forma dissociativa pela qual o neodarwinismo estabeleceu limites entre organismo e seu meio. As mutações epigenéticas (FRANCIS, 2011) também são vistas com agrado por um grupo de biólogos, liderado por Kalevi Kull, que dá sequência às pesquisas da biossemiótica, atualizando e redimensionando o legado do biólogo Jacob von Uexküll (KULL et al., 2004).

O interesse da biologia de Uexküll na antropologia já foi bastante explorado por Tim Ingold (2000) graças à ideia de Umwelt, cunhada pelo biólogo para mostrar que os seres vivos têm uma percepção particular de seu entorno, 
conforme sua constituição corpórea. Os organismos de uma espécie "representam sensorialmente" o mundo de maneira tão específica, que é possível afirmar que há tantos mundos quanto há variedade de capacidades perceptivas das formas vivas, dotadas de sistema nervoso. Uma das ilustrações oferecidas por Uexküll para a relação entre conformação corporal e percepção é a surpresa que pode acometer o adulto que, ao voltar ao lugar de sua infância, constata ser este bem menor do que parecia quando criança. Entretanto, não foi o local que mudou de tamanho, mas a possibilidade perceptiva de seu organismo. Para Uexküll, a natureza é repleta de signos captáveis pelos seres vivos através de seus sistemas perceptivos, ideia que ensejou a formulação da teoria biossemiótica atual por Kalevi Kull (KULL et al. 2009; KULL, 2014), anteriormente mencionado.

A premissa da existência de mundos particulares a cada espécie implica, para o biólogo, a observação e a pesquisa dos aspectos relacionais nos quais todo ser vivo está enredado com especial atenção aos signos investidos de importância: odores, cores, outros corpos. Sinais e indícios captados pelos sistemas perceptivos dos seres vivos ensejam um tipo de representação do mundo por parte destes que, assim, passam a ser compreendidos como sujeitos de sua existência. Essa proposta difere da atual e pode permitir a substituição da ideia convencional de "sobrevivência do mais apto" pela de "convivência do sujeito comunicativo". Ao invés de se imaginar uma natureza bipartida em que há meio seletor e indivíduo selecionado, pode-se supor um conjunto de indivíduos que fazem seus mundos próprios (INGOLD, 2000, p. 176-177).

$\mathrm{Na}$ biologia, há, portanto, pelo menos, duas novas visões teóricas que importam para os antropólogos: um novo papel para o meio ambiente, com as mutações epigenéticas (também chamadas interpretativas), que contradizem a ideia convencional de que as mutações importantes para a dinâmica evolutiva seriam estritamente aleatórias, e a biossemiótica, fruto da recuperação das ideias do etólogo, fisiologista e ecólogo estoniano Uexküll. A primeira abre espaço para a investigação da interferência de práticas culturais sobre a bagagem genética; a segunda, ao estender os limites das formas de atribuição de sentido, para além da capacidade simbólica, característica da espécie humana, pode contribuir para uma reflexão sobre o antropocentrismo (SILVA, 2012) e devolver às sociedades humanas um lugar na natureza.

Se, ao longo do tempo, as mutações epigenéticas e o resgate da semiótica de Uexküll não se mostrarem investimentos tão produtivos quanto seus pesquisadores supõem para a construção de uma alternativa ao darwinismo hegemônico, seja porque este os incorporou a seu próprio modus operandi, seja porque não construíram um paradigma alternativo, pelo menos foram úteis ao 
evidenciarem alguns de seus limites. Esse refinamento da biologia deve interessar à antropologia, pois os problemas advindos da aceitação do princípio da seleção natural dizem respeito também ao objeto comum: o humano. Além disso, como será visto na primeira parte deste trabalho, o entendimento de que aquele princípio se constitui de poderosa expressão do Grande Divisor torna seu exame pelos representantes do campo das humanidades obrigatório, se quiserem enfrentar o desafio colocado pela ruptura epistemológica natureza/cultura. Por isso, também, a grande importância da revisão crítica do neodarwinismo feita por Ingold. No entanto, como se verá na segunda parte deste artigo, o empenho desse autor em corrigir as metáforas elaboradas pelos neodarwinistas, para torná-las mais fiéis ao princípio, é vão, já que tais metáforas apenas traduzem o caráter quimérico do paradigma selecionista. Uma alternativa para fazer biologia e antropologia conversarem é pensar analogias possíveis entre suas premissas, como se verá na terceira parte deste trabalho.

Intento aqui evidenciar que a biossemiótica, antropologia multiespécie, e a antropologia da vida de Ingold são expressões de uma crítica à ruptura instaurada pelo Grande Divisor, que podem ser assim entendidas como respostas românticas, ao buscarem a totalidade perdida por obra do antropocentrismo e do racionalismo ocidental.

A pós-modernidade na antropologia trouxe grandes mudanças, em especial decorrentes desse desafio heurístico - a crítica ao Grande Divisor, tão magistralmente trabalhada por Bruno Latour (1994). Além das reflexões renovadoras trazidas por Ingold, há uma nova modalidade de etnografia, a multiespécie, e o advento da virada ontológica (DESCOLA, 2013), estabelecida com a discussão sobre o perspectivismo ameríndio, que envolvem (em planos distintos) uma concepção de "pessoa" (ou, no caso do perspectivismo, "personitude", conforme VIVEIROS DE CASTRO, 2002, p. 353), que passa a ser estendida a animais não humanos. Na biologia, a epigenética e a biossemiótica, cada uma a sua maneira, reformulam a ideia de indivíduo biológico comum ao neodarwinismo.

O surgimento dos dois lados do Grande Divisor de teorias que refletem sobre uma nova noção de pessoa, extensível aos animais, e que reclamam a valorização da natureza como fluxo, como produtora de signos, para além do símbolo, é aqui entendido como uma reação "romântica" que toma corpo no campo das humanidades e nas ciências da vida². Foi Duarte quem inicialmente caracterizou

\footnotetext{
2 Tal observação segue juntamente com a de que é perceptível uma forte influência das filosofias fenomenológicas e daquelas ligadas ao pragmaticismo, tanto nas ciências sociais quanto nas biológicas, o que merece um investimento específico, que não será feito no presente artigo.
} 
a "pulsão romântica" (DUARTE, 2004). O autor trabalha com a hipótese da existência de uma "cultura ocidental moderna" (e nada indica que isso se altere em condições de pós-modernidade), caracterizada por uma concepção de mundo hegemônica universalista, racionalista e cientificista, mas que, não obstante, se encontra tensionada por outra, a que o autor identifica como "romântica". Esclarece que:

Como a força romântica jamais abateu a pujança do ideal universalista dentro de nosso horizonte ideológico, embora tenha contribuído para tornar seus efeitos infinitamente mais complexos, é preciso reconhecer que as duas forças passaram a, desde o início, operar em tensão permanente. Não de modo recíproco ou igualitário: o romantismo sempre será o contraponto, $\mathrm{o}$ momento segundo de uma dinâmica que o ultrapassa e determina. (DUARTE, 2004, p. 8).

Para Duarte (2004), a dimensão romântica se constrói a partir da ênfase em alguns valores - como a totalidade, a diferença, a ideia de fluxo e a de pulsão -, o primado da experiência, e, finalmente, a ideia de que a ambição da empresa intelectual das humanidades é antes a compreensão do que a explicação. Para ele, ainda, todo o conjunto das humanidades, antropologia incluída, integra essa reação englobada pela hegemônica, científica. E hoje se assiste, internamente ao domínio da biologia, à conformação de pesquisas que propiciam o surgimento da crítica ao neodarwinismo, e cujas características indicam que as ciências "mais duras" não estão a salvo da reação romântica.

\section{Reflexões filosóficas sobre evolução: descoberta ou narrativa?}

Numerosas metáforas já foram utilizadas por geneticistas para explicarem como a seleção natural operaria: um "relojoeiro cego", que montaria um relógio tateando peças ao acaso; ou um "engenheiro cego, surdo e sem presciência", que constrói casa, pontes e máquinas, sem planejamento anterior; ou ainda, ela funcionaria aos moldes de "programa de informática", sem que houvesse, entretanto, um programador. Tais metáforas são ruins, como argumenta fartamente Ingold (2013a, 2019), porque são contradições em seus próprios termos: um relojoeiro tem em mente um modelo de relógio antes de montá-lo e necessita de grande acuidade visual para fazê-lo; não existe programa em informática sem que um programador o tenha feito, e, normalmente, para os engenheiros, o planejamento é parte crucial de sua atividade. A meu ver, ao se 
mostrarem contraditórias, elas evidenciam com fidelidade a estrutura quimérica do princípio, sendo assim perfeitamente adequadas para ilustrá-lo.

São metáforas que evocam teleologia, exatamente como a metáfora central da teoria neodarwinista, sintetizada no termo "seleção natural". Darwin, ao criá-lo, substituiu a criação divina pela "natureza que seleciona", mantendo a ideia de uma entidade abstrata e universal. A despeito dos embates sobre a expressão, travados desde a origem, sobretudo com Herbert Spencer (1893), Darwin manteve o termo, afirmando que era simplesmente alegórico. Estava bastante convencido de que uma espécie se transformava em outra e que cada uma delas representava assim uma variedade da sua ancestral. A observação do naturalista levou à importante conclusão de que as espécies não eram tipos estanques, como queriam os defensores da criação especial, postulada pelos religiosos. E mais do que isso, Darwin chamou a atenção para a importância teórica ${ }^{3}$ do fato de, dentro de uma única espécie, cada indivíduo ser singular e carregar características que poderiam conferir a ele maior capacidade de sobrevivência e de deixar descendência mais numerosa. As variações individuais eram, para ele, a base fundamental da transformação de uma espécie em outra. Sua dúvida era sobre como se dava o processo que originava tais variações.

Argumentei anteriormente (SILVA, 2017) que não só o caráter quimérico da seleção natural, que mantém uma teleologia disfarçada, mesmo que não teológica, teria importância na legitimação desse paradigma. Uma segunda fonte de "invencibilidade" (LATOUR, 1994) do conceito se liga ao fato de, ao se afirmar historicamente como princípio natural que regeria toda evolução, passou a delimitar um campo científico, a saber, o da biologia. Dois ingleses vitorianos apresentaram de forma independente explicações que seguem os limites do Grande Divisor (entre natureza e cultura): Tylor para a evolução estritamente social (ou cultural), em que a diversidade étnica da humanidade era entendida como diversidade de estágios evolutivos. E Darwin, cuja teoria deixava de fora a sociedade "civilizada" (SILVA, 2012). Nesta última, a solidariedade entre os seres humanos teria substituído, segundo o naturalista, a competição pela existência. Assim, a função de epíteto disciplinar pode ter contribuído para a longevidade desse paradigma, que guarda, como já assinalado, imensa consonância com o Grande Divisor (SILVA, 2017).

Um terceiro aspecto que certamente foi fundamental para a permanência desse princípio é que ele permite a supressão dos detalhes de sua narrativa, tendo assumido que a variabilidade individual se dá por mutação genética aleatória, e

\footnotetext{
${ }^{3}$ As diferenças individuais dos seres vivos, fora do campo científico, já eram foco de atenção de criadores e cultivadores.
} 
postulando a intervenção seletora de um meio que agiria como um Deus, moldando as criaturas em prol de sua sobrevivência. Cada desenvolvimento ou processo adaptativos parecem ser, antes, uma narrativa, para qual não há acúmulo de evidências que a sustentem, efetivamente, ilustrando como casos concretos de evolução teriam ocorrido. Assim, mesmo incapaz de ser colocada à prova com relação ao passado ou de predizer o futuro, a seleção natural vem sendo aplicada a todos os níveis - do molecular ao ecossistêmico: "como as bactérias ficam resistentes aos antibióticos? Por seleção natural" ou "como o cérebro humano evoluiu de um cérebro ancestral? Por seleção natural".

Isabelle Stengers (2002) afirma que a biologia é uma ciência descritiva; venho acrescentar que a seleção natural como conceito propicia uma grande narrativa que não descreve propriamente "fatos", mas amarra "fatos" e "suposições" numa grande história. Já Ingold, em artigo inédito, afirmou que a seleção natural é uma "descoberta cuja importância não deve ser desmerecida" (INGOLD, 2019b, p. 4). Essa frase em um texto de Ingold soa incompatível com toda a sua obra e, sobretudo, todas as críticas que ele fez aos neodarwinistas. Pode-se imaginar que seja um alerta para que não se desmereça o papel histórico de Darwin, ponderação com a qual estou de pleno acordo. Não se trata de menosprezar um momento de certo contexto histórico, mas de atribuir outros significados a ele, percebendo-o após mais de um século e meio de seu surgimento. Nesse sentido, lembro que Canguilhem considerou Darwin um vitalista, pois compreendeu a teoria selecionista como "concorrência vital" e não atribuiu consistência às críticas que viam no termo seleção natural uma antropomorfização da natureza (CANGUILHEM, 2012, p. 110-11). O entusiasmo desse filósofo pelo naturalista não foi disfarçado. Entretanto, hoje, mesmo que se considere Darwin um vitalista, não é possível negar que sua principal obra teórica (DARWIN, 2014a) serviu tão plenamente ao desenvolvimento de uma biologia profundamente mecanicista. Minha crítica incide exatamente sobre a expressão seleção natural e seu estatuto de princípio universal, que desenvolvi ao ler os próprios cientistas.

Assim, entender que a ideia seleção natural tem o estatuto de lei geral é entender que ela é muito mais do que "descendência com variação", pois explica toda a diversidade dos seres vivos presente no planeta; essa foi a proposta de Darwin em "A Origem das Espécies". É certo que ele também admitia a possibilidade de evolução através da aquisição de caracteres adquiridos e sua herança à descendência, como propôs Lamarck. Mas o centro de seu argumento foi que a diversidade biológica teria sido produzida basicamente por um mecanismo único, de seleção natural. No início do século XX, o lamarckismo de Darwin foi retirado do neodarwinismo, e outras formas ocasionais de 
diversificação das espécies foram propostas ${ }^{4}$. Esse mecanismo único, justamente como reforça Ingold, não conforma uma teoria da vida, embora ocupe heuristicamente esse lugar. E, como critica Oyama, ela chega a se superpor à ideia de evolução (OYAMA 2000, p. 10-11).

Em um manual sobre o darwinismo contemporâneo (ou neodarwinismo), o autor resume numa curta seleção de excertos, retirados de um livro de Ernest Mayr, intitulado One long argument, a visão, pelo menos aquela sustentada até a chamada década do gene (anos 1990), sobre a importância heurística da seleção natural para a biologia. Ela parece responder às críticas que K. Popper (1975) fez ao conceito por ser descritivo (e não preditivo), o que o destituía da característica de refutabilidade, atributo necessário às teorias para serem consideradas científicas, segundo o filósofo. Afirma E. Mayr:

O darwinismo não é uma simples teoria que possa ser verdadeira ou falsa: é hoje um programa de pesquisa altamente complexo, que está a ser constantemente modificado e aperfeiçoado. (...) Os argumentos [contra o darwinismo] baseiam-se em uma tal ignorância da biologia evolucionista que não vale sequer a pena referir os escritos que os contêm. (...) Os princípios básicos do darwinismo estão mais firmemente estabelecidos do que nunca. (MAYR, 1991, p.143,141 e 164 apud VIEIRA, 2009).

Entretanto, ao contrário do que pensam Mayr e Vieira, em ciência, não deve haver caixa preta que não possa ser aberta. Nesse sentido, em Stengers (2002) são encontradas as melhores formulações sobre os impasses da teoria darwinista:

Avaliada a partir do modelo teórico-experimental, pode-se perguntar se a biologia darwiniana é realmente uma ciência. (...) Que "teoria" os darwinianos hão de acrescentar ao seu ativo, que poderia dar crédito a sua capacidade de julgar, de diferenciar o essencial do anedótico num episódio da evolução? Os grandes conceitos aparentemente explicativos - adaptação, sobrevivência dos mais aptos, etc. - não se revelariam vazios de poder explicativo a priori: simples palavras que comentam uma história depois desta ter sido reconstituída? Avaliada a partir das questões tradicionais suscitadas pela diferença entre os seres vivos e não-vivos, a resposta darwiniana também se mostra fraca. (...) O olho representa por excelência a concepção "tecno-social" do ser vivo. Exige que seja definido como instrumento, meio com vistas a um fim. O olho é feito para ver. Clama por uma concepção do ser vivo que encarnaria o ideal de uma sociedade regida por uma divisão harmoniosa do trabalho. (...) Como não exigir uma forma

\footnotetext{
${ }^{4}$ Secundariamente pelo isolamento reprodutivo, deriva e migração.
} 
de poder finalista para dar conta desta harmonia?" (STENGERS, 2002, p. 168).

A autora acrescenta então que a seleção natural assume o papel do Grande Arquiteto (STENGERS, 2002, p.168) entre os neodarwinistas. Entretanto, as críticas ao paradigma adaptacionista, feitas por cientistas nas décadas de 1970 e 1980, a exemplo daquelas elaboradas por Stephen Jay Gould (2007), e que, aparentemente, não diminuíram em nada, ainda segundo Stengers, o prestígio conferido à comunidade científica ao paradigma selecionista, questionam o papel central ocupado pela seleção natural na explicação darwinista da diversidade viva. Para ela:

A inovação maior de Darwin foi sem dúvida a invenção da história dos seres vivos como história lenta, "deriva" dizia, no sentido em que ela está desprovida do motor que uma capacidade intrínseca de adaptação própria à vida ou à herança dos caracteres adquiridos proposta por Lamarck teria constituído. É em nome desta lentidão, da ação contínua e infinitamente progressiva da seleção, que Darwin tinha desqualificado, como enganadores, os dados da paleontologia, porque estes parecem testemunhos de mutações "bruscas" (em escala de tempo geológico). A teoria dos equilíbrios pontuais de Gould e Eldredge questionou esta avaliação, e implica que a paleontologia possa tornar-se fonte de problemas em vez de ser colocada da dependência da narrativa "adaptacionista. (STENGERS, 2002, p. 169).

Se a seleção é todo-poderosa, se ela não permite construir o ponto de vista a partir do qual todos os casos dariam no mesmo, teriam a mesma moral adaptacionista, o biólogo perde o poder de julgar e deve aprender a narrar. (STENGERS, 2002, p.169-170).

Diferentemente do assinalado por Stengers, para Stephen Jay Gould (2007), a principal contribuição de Darwin foi a percepção da existência de variações fenotípicas individuais. Embora a origem exata de tal variabilidade não fosse muito bem compreendida, seu conhecimento era amplamente aplicado com a antiga prática da seleção doméstica e, portanto, muito bem conhecida por criadores e cultivadores. Mas Darwin mostrou a universalidade do fenômeno e deu a ele um lugar privilegiado em sua teoria explicando-o como fruto do acaso. Foi justamente esse carácter aleatório da variabilidade entre os indivíduos na natureza que assegurou o estatuto de teoria científica ao darwinismo quando comparado ao lamarckismo e, sobretudo, em oposição ao criacionismo. Para Darwin era a criação especial a visão a ser ultrapassada (GALE, 1982, p. 131, 139). 
Barry G. Gale (1982) sustenta que Darwin não voltou da sua famosa viagem a bordo do Beagle com sua teoria pronta, e sim com uma espécie de insight, em que a formulação da teoria precedeu sua argumentação (GALE, 1982, p. 8) 5 $^{5}$ Em 1831 embarcou e fez dessa expedição de 5 anos um grande exercício de observação e de coleta. Dedicou-se, após o retorno à Inglaterra, ao estudo da geologia, pois estabelecer uma idade da Terra diferente daquela bíblica era importante para sustentar seu ponto de vista. Outra questão que dificultava a aceitação da mutabilidade das espécies por parte dos cientistas era a falta de exemplares intermediários entre uma espécie e outra. O primeiro empecilho foi vencido, pois, graças à geologia, a idade da Terra foi considerada muito maior do que até então se supunha. Entretanto, a paleontologia nunca foi eficaz para evidenciar as mudanças graduais imaginadas por Darwin. Mesmo com pontos criticáveis, ele deu a chave para uma narrativa em que qualquer ser vivo poderia ser personagem, sujeito a um princípio comum.

\section{Fluxo ou "avanço criativo para novidade" como metáfora evolutiva}

Em muitos de seus escritos, Ingold submete o neodarwinismo a um detalhado escrutínio, mas foi no livro “Evolução e Vida Social" (2019 [1986]), obra de fôlego em que a separação entre biológico e social é o grande tema, que se dedica mais vigorosa e detalhadamente ao problema. Almeja a compreensão conjunta das dimensões natural e cultural, num só movimento, que algumas vezes denomina "fluxo da vida" (2019, p. 205), indistintamente social e biológica. Ingold (2013b) oscila entre matar o neodarwinismo, decretando o fim de um paradigma, e salválo, transformando a narrativa de Darwin em "descoberta" e criticando as metáforas dos próprios geneticistas sobre como entendem o processo de seleção natural, afirmando que elas não atentam para aspectos importantes da teoria.

Por exemplo, Ingold critica a metáfora do relojoeiro cego (2013a, p. 61-73), cunhada pelo geneticista e sociobiólogo Richard Dawkins para se contrapor à argumentação de $\mathrm{Paley}^{6}$, clérigo anglicano vitoriano, adepto da criação especial

\footnotetext{
${ }^{5}$ Talvez a motivação da obra tenha sido uma acusação da indução contra a dedução. Entretanto, seu valor reside na reconstituição de como Darwin construiu sua teoria.

${ }^{6}$ Paley escreveu Natural Theology em 1802, em que afirmou que se alguém, que jamais tivesse visto um relógio, encontrasse um caído em uma estrada, iria deduzir facilmente que alguém criara aquela peça. Com essa metáfora quis dizer que basta olhar para a natureza para ali ver Deus, o relojoeiro. Darwin, em 1827, entrou na Universidade de Cambridge e leu o livro de Paley, embora a obra não fosse central no currículo: "In a few years Darwin reversed the logic of Paley's argument from a fixed state into a process by which species adjust to changes in their environment by natural means". (BOWLER, 2009, p. 149)
} 
e do design inteligente. Dawkins cria a metáfora do relojoeiro cego para explicar como opera a seleção natural, i.e., a construção de coisas que funcionam e que parecem planejadas, mas não o são. De acordo com o sociobiólogo, a diversidade das espécies é obra do acaso; não havendo plano diretor na evolução. Dawkins quer, com a imagem de um relojoeiro cego, evidenciar como alguém, por tentativa e erro, juntando peças surgidas aleatoriamente, tateando o que encontra sobre a mesa de trabalho, constrói uma máquina funcional e precisa. Ingold mostra, com razão, como a metáfora é ruim, pois, justamente pelo ofício de relojoeiro exigir grande capacidade manual e acuidade visual, é auxiliado muitas vezes ainda por lentes de aumento típicas da profissão. Em suma, um relojoeiro cego jamais construiria um relógio. Além disso, não há nenhuma semelhança entre o funcionamento da natureza e o de um relógio.

O mesmo tipo de crítica, feita por Ingold a Dawkins, é por ele lançado a outras "analogias altamente enganosas" (INGOLD 2019a, p.199), propostas por outros cientistas, embora guardando o mesmo sentido, qual seja, rechaçando-as por atribuírem teleologia ao processo de seleção natural. Para Ingold, se há teleologia, a criatividade ou novidade seriam necessariamente dirigidas a esse fim, constituindo, portanto, um processo ou evento nem criativos, nem livres para darem lugar ao surgimento do novo. Muitos "neodarwinistas importantes" (INGOLD 2019a, p. 199) comparam a seleção natural a um artista, a um escultor, bricoleur, enfim, a um idealizador, o que traz de volta para o centro da cena orgânica a teleologia que, conforme afirma, Darwin quis expulsar. Monod é criticado por negar a entidade criativa, ao considerar que cada organismo é uma máquina autoconstruída a partir exclusivamente do acaso. Ingold argumenta então que eventos aleatórios não criam, eles apenas acontecem (2019a, p. 198) ${ }^{7}$.

Dobzhansky admitia ser legítimo considerar a seleção natural como uma espécie de engenheiro, desde que cego e mudo, e destituído de presciência, de modo que cada ato da construção é ele mesmo uma decisão sobre o que deve ser construído (INGOLD, 2019a, p. 197). Mas Ingold argumenta que "como Dobzhansky bem sabe, a significação principal do ensinamento darwinista está em sua manifestação de como é possível o devir de estruturas adaptáveis ou teleonômicas na ausência de um projetista criador" (INGOLD, 2019a, p. 198).

Ainda em "Evolução e Vida Social" (2019 [1986]), Ingold organizou uma extensa revisão bibliográfica e uma leitura própria do problema da dupla existência do ser humano, a social e a natural. O objetivo central da obra é estabelecer uma compreensão do processo social como uma dimensão não

7 Frase que leva à suposição de que a criação, para Ingold, tenha que ser um acontecimento com sentido. 
apartada do fenômeno da vida em geral. Para tanto, apoiou-se nas formulações de Henri Bergson e Alfred North Whitehead, em especial a ideia de "avanço criativo para novidade", deste último, que abarca também os diferentes modos da vida cultural. Ao longo do livro, e sobretudo no capítulo Chance, Necessity and Creativity, o autor expõe o que vem a ser o fenômeno da criatividade, isto é, do surgimento do novo, desmerecido por aqueles três "ismos" - mecanicismos, determinismos e finalismos - comuns à ciência biológica.

Ingold recorre às formulações do geneticista Theodosius Dobzhansky e do bioquímico Jacques Monod, eminentes criadores daquela teoria, para contrastar a concepção de organismo como máquina, partilhada pelos dois cientistas, embora de formas diferentes, com a ideia de organismos como "concrescências", i.e., produtos do "avanço cumulativo da organização na qual a natureza sempre se sobrepuja" (INGOLD, 2019a, p. 194), desenvolvida originalmente por Whitehead. Ingold ressalta que, para esse filósofo, a criatividade se dá "no próprio momento do devir" (2019a, p. 194), enquanto para os seguidores de Darwin essa forma de entendimento inexiste:

Whitehead atribui a criatividade da evolução orgânica a outra coisa que não a adaptação sob seleção natural. Comparemos sua concepção de que "o sentido primordial da vida é a criação da novidade conceptual" (WHITEHEAD, 1929, p. 142) com a de Dobzhansky, de que o organismo vive para realizar o concepto novo do qual é uma corporificação e cuja criação, por isso, deve estar fora da vida. (INGOLD 2019a, p. 205)

Diferentemente dos biólogos, que, com frequência, utilizam evolução e seleção natural como sinônimos, Ingold distingue a primeira, que é o fluxo, da segunda, que seria o processo que contribui para o fluxo como um todo:

A "descendência com modificação" darwiniana, como já demonstramos, conota uma sequência mutante da forma $B_{1}, B_{2}, B_{3}, \ldots$ onde $A$ é substituído por acaso (variação) e antiacaso (seleção). Dobzhansky, lamentavelmente, emprega o termo "evolução" tanto para o mecanismo da variação sob seleção natural como para o resultado da descendência com modificação, e é por isso que pode falar simultaneamente do aparecimento de formas novas na evolução e da evolução como uma força que cria ou traz novidades à existência (...) O essencial a aprender, contudo, é que em nenhum sentido pode a evolução ser comparada com o fluxo da vida. Não podemos dizer que o organismo evolui enquanto vive porque no paradigma darwinista ele só pode ser concebido como um objeto evoluído, um em uma sequência desses objetos. (INGOLD, 2019a, p. 205). 
O princípio da seleção natural, utilizado por Darwin como metáfora da natureza, retira, na visão de Ingold, como teoria científica, os organismos do fluxo da vida, considerando-os como obras acabadas e dele separadas. A seleção natural não é, para ele, o móvel nem da criatividade nem da diversidade viva, de autoria do próprio fluxo. A seleção natural é o processo que, para Ingold, retira os organismos do fluxo. Retirados do fluxo, não mais evoluem, apenas sobrevivem. É o que fica claro na passagem em que se contrapõe ao argumento do filósofo Thomas Anderson Goudge:

Ao tratar a seleção natural como um agente duplamente criativo, Goudge está duplamente errado. A seleção não cria mas ocupa o lugar de um criador. Ela só pode explicar a construção de coisas vivas como objetos mecânicos. (INGOLD, 2019a, p. 194).

Ingold mostra que o finalismo e o mecanicismo têm em comum limites heurísticos por suas respectivas formas de representarem os organismos. $\mathrm{O}$ finalismo atribui às totalidades uma finalidade, e o mecanicismo as veem como produto de partes que se ajustam para aquele fim. A ideia de que "uma necessidade" está subjacente à vida é encontrada tanto nas explicações mecanicistas quanto nas finalistas. Para o autor, ambas as explicações não percebem a criatividade como a base do fenômeno vivo, descrevendo os processos segundo uma ótica utilitária:

(...) O finalista afirma que todas as coisas vêm a ser como partes de um programa organizado de antemão, e por isso seu surgimento equivale apenas a uma revelação. O mecanicista também reduz toda realização a um programa, mas trata-se daquele que veio a existir com a máquina, em vez de antes de sua realização na mente na mente de um criador, e que, consequentemente, resta ser descoberto e compreendido pelo intelecto humano. (...) $\mathrm{O}$ finalismo radical, embora descarte o acaso, não pode oferecer nenhuma solução para o dilema. Se cada estado remontar a uma intenção antecedente ainda temos que explicar a criação dessa intenção. $O$ protótipo dessa espécie de finalismo é a imagem de uma pessoa que propositalmente constrói um artefato segundo um modelo que existe pronto em sua mente. Mas de onde veio o modelo? Voltando às duas espécies de criatividade de Wieman, a execução de um plano é o "fazer de uma pessoa", como quando A faz B. Mas sua origem está naquilo por que a pessoa passa, a saber, a vida de A. Assim como faz, o homem vive; portanto, tão logo se dedica a empreender um plano, ele já foi além da intenção original. Há algo na ação que não foi dado em suas condições iniciais, algo de que nem o mecanicismo nem o finalismo podem dar 
alguma descrição que seja. (INGOLD, 2019a, p. 224-225).

Ingold ainda argumenta que a realidade não é uma sucessão de estados, e sim um processo contínuo, no qual nada, vivo ou não, persiste. Conclui que, se nada persiste, nada é necessário: “É precisamente esse o dilema ao qual somos levados ao reescrevermos a vida da sociedade como vida social das pessoas" (INGOLD, 2019a, p. 224-225). Aqui Ingold sintetiza um problema que está na filosofia e na ciência - sobretudo a neodarwinista - e, conforme visto, também é argutamente referido por Stengers (2002, p. 168), de não poderem "separar o que é essencial do anedótico".

A metáfora do "fluxo da vida" (ou "fluxo da experiência" ou "avanço criativo para novidade") evita o problema da origem ao mesmo tempo em que tenta ser fiel à dinâmica do mundo em si. Não se propõe a explicar, mas a apreender. A metáfora do fluxo quer ainda ilustrar uma realidade menos atomizada do que aquela com que a ciência trabalha, o que faz com que não aceite a concepção de novidade ou de criatividade como eventos produzidos ou coisas feitas. Ingold lembra a afirmação de Anthony Giddens de que a intencionalidade é um fluxo e não uma sucessão de estados e que só "a monitoração reflexiva da ação", num olhar retrospectivo, é que dá a impressão de algo sempre totalmente consciente e passível de cortes.

Ingold afirma que a vida social das pessoas é mais bem descrita e entendida como a vida social por meio das pessoas. Ela é a duração das concrescências - sejam estas pessoas ou coisas - que se materializam no fluxo evolutivo. A criatividade se dá por meio das pessoas. Além disso, deve-se assumir uma representação topológica de pessoa, ou seja, entendê-la não como um organismo discreto, mas como o lugar de um crescimento criativo em um campo total de relações intersubjetivas e acrescenta que "vida real sempre tem caráter de trabalho em andamento" (INGOLD 2019a, p. 228)

Ingold, (2019a, p.223) ao sustentar que "o resultado de nossa dissecação analítica do fluxo da experiência e sua reconstituição como uma sucessão de estados é a decomposição da duração em sincronia e diacronia, do movimento em persistência e mudança e da criatividade em necessidade e acaso", quer dizer que tal dissecação redunda em uma forma de decompor a experiência em dualidades que a empobrecem.

É importante ressaltar que, em nenhum momento, Ingold propõe que "fluxo" seria melhor metáfora para ilustrar a teoria da seleção natural. Apenas quer distinguir a Evolução como vida em processo, e a teoria (darwiniana), que, segundo afirma, explica como os organismos contribuem para a evolução geral. 
Considero, entretanto, que seleção natural é uma teoria produzida por uma visão científica mecanicista, distinta da filosofia vitalista, de que se serve Ingold. A singularidade orgânica é, para a ciência biológica, basicamente conferida pelo genoma, para qual também há uma clara distinção entre o processo de produção de um ser (ontogênese) e o ser (como produto). A ênfase dada à "transmissão genética" e o sucesso explicativo do determinismo genético, comuns entre os pesquisadores, realmente evidenciam que a representação de organismo pela ciência o aproxima antes das máquinas do que das concrescências criativas, concorrendo para um grande fluxo, em constante movimento. Ingold, ao contrário, apoiando-se em Bergson, sustenta que "o princípio criativo é consubstancial com o trabalho criado, e não separado dele" (2019a, p. 203):

Nosso interesse, nessas últimas poucas páginas, foi o modo de criatividade que governa a construção de entidades novas, sejam elas orgânicas ou culturais, criando historicamente uma sequência mutante cujos elementos são não recorrentes. E como quer que interpretemos o agente criador, seja como engenheiro ou como bricoleur, operando por meio de seleção interna ou externa, a criatividade contida é essencialmente mecanicista, uma vez que realizada por uma combinação de inovação randômica e reorganização de itens preexistentes. Chegou a hora de voltar à outra espécie de criatividade, expressa na fórmula "A vive", oposta à "A faz B (...). [a primeira fórmula] pertence ao processo intersubjetivo da vida social, um processo no qual a pessoa está sempre se tornando com o passar do tempo." (INGOLD, 2019a, p. 223).

É fácil concordar que a proposição de Ingold é oposta àquela do neodarwinismo. A metáfora do "fluxo" enfatiza o movimento, o avançar, sem um ponto de chegada, como observa Duarte (2004, p. 10) ao caracterizar as dimensões constitutivas do romantismo como força de tensão interna à ideologia ocidental. Ingold observa que a "novidade", no sentido atribuído por Whitehead, é o que mantém o fluxo evolutivo. Qual seria a possibilidade da transformação desse paradigma em uma teoria da vida, ou seja, numa filosofia vitalista? Nenhuma, já que o compromisso com a filosofia cartesiana está evidente.

Além de um peso muito grande na novidade como fonte de criatividade ou, por outra, além dessa ideia de "fluxo" conter uma radicalização da criatividade e estar sempre orientado em direção a uma novidade igualmente radical, ela implica, a meu ver, uma homogeneidade. Talvez a noção de meshwork, cunhada por Ingold em publicações mais recentes (por exemplo, INGOLD, 2011), seja uma metáfora com maior verossimilhança. Ademais, a ideia de fluxo, como se lê em Duarte (2004, p. 10-11) em sua análise do ideal romântico, envolve uma 
teleologia, um constante movimento à frente. Nesse mesmo sentido, considero que fluxo, como metáfora referida à evolução, tal como propõe Ingold, padece de finalismo, tanto quanto as metáforas selecionistas.

Finalmente, considero que os termos - relojoeiro cego", "engenheiro sem capacidade preditiva", "Grande Arquiteto" ou a de "programa" de computador - representam com perfeição o caráter quimérico do atual paradigma da seleção natural, e, portanto, não precisam ser criticadas. É certo que o acaso e a contingência (LEWONTIN, 2001, p. 27) são formas de pensar os eventos fundamentais para a compreensão da vida como fenômeno, mas atribuir às "mutações ao acaso" a base a partir da qual se constitui a diversidade viva é uma premissa vetusta, que hoje pode ser reavaliada. Na passagem do século XIX para o XX, a fórmula da aleatoriedade garantiu a chancela de cientificidade da teoria. Atualmente ela é inadequada. Ademais, se houve a ativa aceitação da seleção natural como princípio explicativo da diversidade viva por parte dos antropólogos - e aqui nem me refiro à antropologia evolucionista - em seus trabalhos (ver GEERTZ, 1978; LÉVI-STRAUSS, 1976a, por exemplo), o que impediria a aceitação da sua crítica?

\section{A Umwelt, o perspectivismo e a multiespécie: atenção voltada para os "mundos interiores"}

Nas sessões anteriores busquei chamar a atenção para o fato de o princípio de seleção natural expressar a ruptura trazida pelo Grande Divisor, mas que, como explicação da natureza, é falho. Esse diagnóstico vem ensejando o surgimento de visões alternativas, dentro do próprio campo das ciências biológicas, por exemplo, os trabalhos sobre epigenética (analisados alhures, SILVA; DUARTE, 2016) e a biossemiótica de Kalevi Kull, aqui apenas referida, devendo ter aprofundamento em trabalho futuro. $\mathrm{Na}$ antropologia, o questionamento da díade que funda sua própria constituição, natureza/cultura, abriu espaço para o surgimento da etnografia multiespécie e, na etnologia sul-americana, acredito ter contribuído para a conformação da teoria perspectivista, o que será esclarecido a seguir. Também a antropologia da vida, de Tim Ingold, é uma expressão desse mal-estar com relação à centralidade da permanência do Grande Divisor no pensamento científico.

O cerne das críticas de Ingold, e que foi extensamente exposto em Perception Of The Environment (cf. 2000), é justamente o colapso heurístico das dualidades cartesianas derivadas da mais central - corpo/mente - a partir da fenomenologia, sobretudo de Gibson, cuja psicologia ecológica, próxima, por sua vez, da biologia 
de Uexküll (cf. 1982, 2008), vai de encontro às premissas racionalistas sobre as quais repousa a antropologia cognitivista e, por que não?, grande parte da antropologia. Ingold se inspira também em Gibson para afirmar que "o modelo é o mundo" $(2000,166)$. Assim, por essa via de adesão aos processos concretos de vida é que ele vai criticar os mecanismos e reducionismos de antropólogos e biólogos e suas metáforas. Ingold está sempre pronto a questionar a improdutiva disciplinaridade da ciência (In OYAMA; GRIFFITHS; GRAY, 2001).

Ingold (2006, 2019a) questiona a visão, endossada pelo darwinismo, de que o ser humano seria o único animal a ter uma dupla história - a social e a biológica -, distintamente dos outros animais: todos temos uma única história, que é social e biológica ao mesmo tempo. O autor opõe-se, portanto, à ideia de uma natureza orgânica coroada pela autoconsciência que conferiria um insuperável corte ontológico entre humanos e não humanos ${ }^{8}$. Para ele, que aí se inspira ${ }^{9} \mathrm{em}$ Oyama (2001), os “organismos são pessoas" (INGOLD, 2006, p. 29), isto é, são o "desdobramento criador de um campo total de relações, nos quais os seres aparecem e tomam suas formas particulares, cada um em relação aos outros" (2006, p. 30).

Talvez seja necessário observar que aqui se trata, então, de uma concepção de "pessoa", muito diferente daquela estabelecida pela clássica análise de Marcel Mauss, em seu ensaio de 1938 (MAUSS, 1974), e que tem sido a referência para os antropólogos que se voltam para o tema, entendendo-a como uma categoria do pensamento. A noção de pessoa atribuída aos organismos vivos, aqui em jogo, é uma conjugação de um atributo maussiano - a consciência de si - com outros, comuns à biologia do desenvolvimento. Para Mauss, e o autor referia-se apenas às sociedades humanas, a noção de "pessoa" tem muitas dimensões, mas, antes de mais nada, corresponde a uma condição da autoconsciência (MAUSS, 1974, p. 239). Entretanto, para Ingold, aqui inspirado em Uexküll, essa autoconsciência não decorre de um fator adicional a um organismo, como quer a tradição cartesiana da qual Marcel Mauss faz parte, sendo produto do desenvolvimento do próprio organismo. Ingold (2006), indo também ao encontro das formulações de Oyama (2001), sustenta que "ser um organismo" não é, entretanto, a coisa mais simples do mundo:

A forma orgânica é um atributo que aparece como propriedade emergente dos sistemas de desenvolvimento, então, a evolução da forma não depende

\footnotetext{
${ }^{8}$ Latour inclui na categoria não humanos os objetos. Aqui o termo se refere somente aos animais.

${ }^{9}$ Há uma ideia análoga em Uexküll, como se verá a seguir, que os animais são "sujeitos", o que também é uma referência para Ingold (2000, p. 176).
} 
das mudanças de frequência dos genes: a evolução da forma tem lugar no desdobramento de um campo relacional total. E, nesse processo, os organismos podem tanto desempenhar um papel de produtores quanto de produtos de sua própria evolução uma vez que, por meio de suas ações, eles contribuem ao mesmo tempo para as condições ambientais de seu próprio desenvolvimento para aquelas do desenvolvimento dos outros animais com os quais eles estão em relação. Na medida em que é engendrado nesse processo e também o prolonga, cada ser aparece como um núcleo indiviso de consciência e de ação intencional: uma concentração (em torno de algum ponto de conexão que lhe é próprio) do potencial gerador que é a própria vida. (INGOLD, 2016, p. 30).

Para tanto, considera ser fundamental discernir entre intencionalidade e pensamento estratégico. Intencionalidade é a capacidade de o ser vivo agir, baseando-se em sua sensibilidade; não é, necessariamente, produto de qualidades cognitivas complexas, o que demandaria um sistema nervoso compatível. Assim, a atribuição de passividade e de ausência de motivação intencional aos animais não humanos pode ser fruto do preconceito fundado na equivalência entre intenção e pensamento estratégico ${ }^{10}$.

Essa mesma ideia já havia sido de alguma forma defendida alhures (cf. INGOLD, 2007) ao afirmar que, embora os não humanos não pensem (como nós, humanos), isso não significa que não tenham um tipo de autonomia e criatividade frente ao contexto. O grau de refinamento dessa autonomia e capacidade de criar situações novas dependerá evidentemente, como já foi dito, do tipo de organismo. O que é mais significativo é que estamos todos, como pessoas, envolvidos em uma atividade de autocriação ao mesmo tempo de criação dos outros. Para o autor, o organismo (ou pessoa) não pode ser tomado como uma unidade discreta e pré-programada, mas como um campo contínuo de relações, contrapondo-se assim ao determinismo genético, segundo o qual os seres vivos são expressões de seus genes, caro ao neodarwinismo. A noção de pessoa, que aqui se delineia, caracteriza-se, portanto, pela consciência de si, capacidade de agência criativa e existência relacional (ou social, em minhas próprias palavras). Essas propriedades não são adicionadas a uma base orgânica, mas surgem dela e com ela, o que propiciou Ingold a recorrer às ideias de Jakob von Uexküll, biólogo cuja teoria se opôs ao mecanicismo que, nas primeiras décadas do século XX, já era hegemônico nas ciências biológicas.

\footnotetext{
${ }^{10}$ A sociobiologia considera que os seres vivos são meios de replicação de seus próprios genes que atuam como apostadores que buscam maximizar suas chances de replicação. Assim, ao mesmo tempo em que reservam um papel passivo aos organismos, como se fossem máquinas, atribuem um papel totalmente diligente ao genoma (SILVA, 1993, 2006).
} 
A ideia de Umwelt, cunhada por Uexküll, e que foi traduzida para o português como "mundo próprio" (UEXKÜLL, 2008), designa a forma particular de apreensão do mundo por cada espécie animal, conforme os sinais que o animal percebe nesse seu entorno e, com relação a esses sinais, elabora respostas. Essa percepção (e a resposta consequente) é determinada por seu aparato sensorial, por seu sistema nervoso, em uma palavra, por seu organismo. Cada espécie animal teria, por isso, um mundo seu, próprio, uma "bolha" (ou "bola de sabão", como se lê abaixo, na tradução portuguesa), dentro do ambiente mais amplo, o que não é o mesmo de se dizer que cada animal tem uma maneira específica de experimentar um mundo comum, se esse mundo comum for considerado como externo, neutro, para o qual haja única representação realmente válida. A Umwelt é a díade percepção/ação do animal no mundo:

Quem se agarrar ao preconceito de que todos os seres vivos são apenas máquinas, perde toda a esperança [p. 23] de vir jamais a lobrigar os seus mundos-próprios [p. 24]. (...). [Ao se considerar] os animais não como meros objetos, mas como sujeitos, cuja atividade essencial consiste em assinalar e atuar (...) abre-se já a porta que conduz aos mundos-próprios animais, porque tudo aquilo que um sujeito assinala passa a ser o seu mundo-depercepção, e o que ele realiza, o seu mundo-de-ação. Mundo-de-percepção e mundo-de-ação constituem uma unidade íntegra - o mundo-próprio do sujeito. [UEXKÜLL, 2008, p.24]

Os mundos-próprios, que são tantos quantos os próprios animais, oferecem a qualquer admirador da Natureza novas terras, tão ricas e tão belas que compensam bem uma excursão através delas, mesmo quando elas se não patenteiem aos nossos olhos materiais mas somente à nossa visão espiritual. As melhores condições para iniciar tal digressão são um dia de verão e um prado coberto de flores, ressoante de zumbidos de coleópteros e pululante de adejares de borboletas; então construiremos para cada animal dos que povoam o prado, uma como que bola de sabão, que [p. 25] represente o seu mundo-próprio, preenchida por todos aqueles sinais característicos que são acessíveis ao sujeito. Logo que entremos numa dessas bolas de sabão transfigura-se completamente o mundo ambiente que se abria em volta do sujeito. Muitas qualidades do variegado prado desaparecem inteiramente, outras perdem as suas propriedades gerais; surgem novas correlações. Em cada bola de sabão passa a existir um mundo novo. [UEXKÜLL, 2008, p. 23-27]

Para a biologia semiótica, sendo o mundo externo função do interno, a distinção entre uma realidade externa única e uma apreensão interna específica, que representaria parcialmente o mundo comum, não procede. Noto assim uma 
certa confluência entre biólogos semióticos e etnólogos a propósito da ideia de uma natureza ontologicamente múltipla, o que é ilustrado pelo perspectivismo, como se verá a seguir.

Kalevi Kull, herdeiro da biologia de Uexküll, incorpora à sua abordagem biossemiótica11 os resultados experimentais das "mutações epigenéticas", considerando que estas possuem importância capital para a evolução. Para ele, as mutações epigenéticas precedem as genéticas no processo evolutivo. Ele conjectura que uma população, ao enfrentar novas condições ambientais, pode passar por ajustes fisiológicos que mudam seu fenótipo, sem mudar o genótipo, ou seja, sofre uma mudança epigenética. Se a população passa tais modificações à descendência, graças à herança epigenética, o novo fenótipo se torna permanente. Se, com os acasalamentos, essa mudança epigenética se tornar genética e, portanto, irreversível, esse processo ensejou o surgimento de uma nova espécie. Para Kull, então, são os acasalamentos que mantêm a população dentro de certos limites de variabilidade. Diferentemente do princípio de seleção natural, trata-se de uma hipótese sobre um processo relacional e não da ação ambiental sobre um gene. Kull (2014) afirma:

Se pudermos contrastar dois mecanismos da evolução adaptativa - o neodarwinista e o semiótico - precisamos descrever como um mecanismo individual versus outro relacional. A SN é baseada na replicação de traços genéticos exibidos por um indivíduo. A semiótica descreve um vínculo coletivo de uma escolha orgânica. É um processo puramente relacional. (KULL, 2014, p. 291)

A ideia de Umwelt, central na biossemiótica, abre espaço para a de que há mundos distintos que coexistem, o que pode remeter ao "multinaturalismo" do perspectivismo:

O relativismo cultural, um "multiculturalismo", supõe uma diversidade de representações subjetivas e parciais, incidentes sobre uma natureza externa,

\footnotetext{
${ }^{11}$ Ainda estou lidando com as reverberações internas de trabalhos anteriores (SILVA; DUARTE, 2016; SILVA, 2017) e do curto estágio pós-doutoral (setembro 2014- maio 2015) na Universidade de Aberdeen onde pude me beneficiar das discussões ocorridas no grupo do qual participavam professores pesquisadores e estudantes daquela Universidade e a de St Andrews. Esse grupo foi idealizado e liderado pelo biólogo Murilo Pagnotta, doutorando de St Andrews na época e tinha como foco a discussão sobre a possibilidade de síntese entre biologia e antropologia. Também em Aberdeen, o evento comemorativo dos 15 anos da publicação do Perception of environment (INGOLD, 2000) foi bastante rico e tive contato com pesquisadores que pensam a evolução do ponto de vista da biossemiótica. Uma das pesquisadoras presentes me disse: "você é uma das nossas"; embora tivesse dúvidas sobre este diagnóstico, a possibilidade de encontrar "uma turma" foi reconfortante.
} 
una e total, indiferente à representação. Os ameríndios propõem o oposto: de um lado, uma unidade representativa puramente pronominal - é humano quem ocupa vicariamente a posição de sujeito cosmológico; todo existente pode ser pensado como pensante ("isto existe, logo isto pensa"), isto é "ativado" ou "agenciado" por um ponto de vista -; do outro lado, uma radical diversidade real ou objetiva. O perspectivismo é um multinaturalismo, pois uma perspectiva não é uma representação. (VIVEIROS DE CASTRO, 2015, p. 65)

Ensejando o movimento referido como virada ontológica (DESCOLA, 2013), etnólogos, ao pesquisarem entre os povos das Américas, propuseram a existência de uma "ontologia perspectivista" (LIMA, 1996; VIVEIROS DE CASTRO, 2002, 2015), característica de inúmeros povos originários do continente:

O tema deste ensaio é aquele do pensamento ameríndio que manifesta sua "qualidade perspectiva" (...) segundo a qual o mundo é habitado por diferentes espécies de sujeitos ou pessoas, humanas e não-humanas, que o apreendem segundo pontos de vista distintos. Os pressupostos e consequências dessa ideia são irredutíveis (como mostrou Lima, 1995, p. 425-38) ao nosso conceito corrente de relativismo, que à primeira vista parecem evocar. (...) [Ao contrário das cosmologias multiculturalistas modernas] a concepção ameríndia suporia, ao contrário, uma unidade do espírito e uma diversidade dos corpos. A cultura ou sujeito seriam aqui a forma do universal; a natureza ou o objeto, a forma do particular. (VIVEIROS DE CASTRO, 2002, p. 348-349)

O ser humano se vê a si mesmo como tal. A lua, a serpente, o jaguar e a mãe da varíola o veem, contudo, como um tapir ou um pecari, que eles matam" anota Baer sobre os Machimguenga. Vendo-nos como não-humanos, é a si mesmos que os animais e espíritos veem como humanos. (VIVEIROS DE CASTRO, 2002, p. 350)

O fenômeno do perspectivismo consiste, então, na visão, partilhada por povos ameríndios, segundo a qual o aparato físico dos animais (e outros entes) lhes confere perspectivas específicas do mundo, e de si, de tal modo, que não humanos podem se ver como humanos. Geralmente, o perspectivismo é restrito a alguns seres que, então, teriam a propriedade de se verem como humanos ao mesmo tempo em que enxergam os humanos como não humanos. Tal propriedade de se ver como "pessoa", de ter uma "perspectiva", não seria atributo da essência de uma espécie (biológica), ou entidade. Exercer um ponto de vista específico é função da situação de alguém (ou algo) em relação a outros. E, finalmente, no perspectivismo, "todo ser a que se atribui um ponto de vista 
será então sujeito, espírito; ou melhor, ali onde estiver o ponto de vista, também estará a posição de sujeito". (VIVEIROS DE CASTRO, 2002, p. 373).

Se especificidades do perspectivismo o afastam muito da teoria semiótica, centrada na ideia de Umwelt, ambas visões têm, entretanto, em comum o fato de estenderem a seres não humanos a condição de sujeitos ou pessoas, além de isso ensejar a pluralidade de mundos coexistentes sem que haja um único, considerado universal, neutro, objetivo. Uma das coisas que está em jogo em "A Ciência do Concreto" (LÉVI-STRAUSS, 1976b) é a possibilidade de coincidência entre a classificação científica e a nativa; analogamente, mas em sentido muito diferente do que o de afirmar uma realidade positiva que pode ser evidenciada por meios diversos, o que está sendo aproximado aqui é o aspecto perspectivo coincidente entre a biossemiótica de Uexküll e a visão dos ameríndios. No caso da ciência semiótica, a capacidade perspectiva é conferida por seu organismo, seu aparelho perceptivo; no caso dos ameríndios, o lugar que ocupa em seu mundo.

A etnologia "inscreve" (LATOUR, 2000) o perspectivismo no momento da disciplina em que há o acirramento da crítica epistemológica ao Grande Divisor. A maneira de refletir sobre o que os nativos pensam, isto é, que animais não humanos também possuem pontos de vistas, acontece concomitantemente ao surgimento de inquietações mais amplas provocadas pela crítica ao Grande Divisor, trazida para a antropologia, conforme já dito, por Bruno Latour (1994), e sua imensa gama de consequências, entre as quais a noção modificada de "pessoa", que não coincide estritamente com a de pessoa humana, nem se confunde com a da pessoa maussiana.

$\mathrm{Na}$ etnologia ameríndia encontra-se também uma outra inspiração da semiótica, a de Peirce, como ilustra o trabalho de Kohn $(2007,2013)$, para quem a natureza é dotada de significado intrínseco. Ao pesquisar junto aos Runa, povo da Amazônia equatoriana, Kohn (2013) apoiou-se na distinção feita por Peirce sobre três formas de signos - índice, ícone e símbolo - e aceitou o entendimento dos Runa, segundo os quais o mundo é dotado de significado intrínseco. O índice peirceano é uma espécie de signo que permite ao interpretante ligar alguma coisa (uma visão, um ruído, um cheiro) a outra, que é apenas potencial. Um macaco numa árvore, por exemplo, que ouve um barulho de galho quebrando, pode rapidamente suspeitar que uma onça escala o tronco ao seu encontro e foge rapidamente para um lugar que o afaste de onde o som veio. Assim, todos os seres têm uma interpretação de seu mundo, consoante as possibilidades de sua percepção (UEXKÜLL, 1982) dos signos. Kohn quer justamente deixar de lado o Grande Divisor que pressupõe uma natureza que funciona tal como um relógio, 
montado por um relojoeiro cego. Ele afirma:

Em suma, como a vida é semiótica e a semiose está viva, faz sentido tratar vidas e pensamentos como "pensamentos vivos". Essa compreensão aprofundada da estreita relação entre vida, eu e pensamento é central para essa antropologia além do humano que estou desenvolvendo aqui. (KOHN, 2013, p. 78).

A aposta na superação do Grande Divisor, incorporando o não humano ou o "beyond the human", dentro da antropologia, tem várias dimensões, mas certamente se ligam às críticas de Latour (1994) endereçadas à postura dos antropólogos, que adotaram um relativismo reificador do Grande Divisor (tão bem marcado pelas obras originárias de Darwin e Tylor): a cultura pode ser relativizada, mas o universalismo continuava aplicado à natureza. E, no contexto de grande questionamento da ciência como guardiã da díade natureza/cultura, vêm surgindo, também no Brasil, inovadores trabalhos ligados ao fazer científico e às atividades em laboratórios, como os de Fonseca e Garrido (2018), Luna (2012), Manica (2018), Monteiro (2009), Nucci (2010), Vassalo (2018) e Sá (2010) para citar alguns.

As etnografias identificadas como multiespécie (KIRKSEY; HELMREICH, 2010) abrangem uma extensa gama de trabalhos que, em comum, têm a busca de compreensão das relações humanos/não humanos, no tocante às espécies vivas, como a predação, a domesticação, o cultivo, a extração, etc. Geralmente elas apontam para a subjetividade e a capacidade de agência inerentes a outros animais - e mesmo plantas (ALMEIDA, 2016), sem falar em seres tão esquisitos quanto inspiradores de metáforas como os fungos (TSING, 2015 -, qualidades que são desmerecidas pela visão científica ocidental, ou então por outros segmentos ou grupos sociais distintos daqueles em foco naquela etnografia. Trata-se de um desdobramento de uma discussão, nem sempre explícita nesses trabalhos, sobre antropocentrismo.

Como afirmei, é possível o entendimento dessas reformulações que ocorrem concomitantemente nos campos da biologia e da antropologia como respostas "românticas" (DUARTE, 2004) à visão mecanicista da natureza promovida pelo neodarwinismo e ao antropocentrismo que perdura tanto na produção antropológica quanto na biológica. Assim, a despeito das grandes diferenças existentes entre os autores, é nesse "solo" (romântico) comum que prosperam obras como a de Latour, em sua busca de uma simetria no fazer científico, a de Tim Ingold, que almeja fazer uma antropologia da vida, e a de gerações mais recentes de etnógrafos, como Nadasdy (2007), cujas etnografias podem ser 
consideradas representantes da modalidade identificada como multiespécie, desdobramento decorrente da crítica do Grande Divisor, e que, a exemplo de Kohn, $(2007$, 2013), podem incorporar a semiótica de Charles Peirce, expandindo a ideia de significado para além daquela que foi a marca da análise LéviStraussiana. É premissa de todos esses trabalhos que animais não humanos também podem ser considerados "pessoas" ou, então, considerados "como se" fossem "pessoas".

Existe uma crucial diferença entre conceber que não humanos podem ser pessoas e acreditar que não humanos são como pessoas (INGOLD, 2000, p. 51). O perspectivismo se refere à primeira concepção, pois o que está em jogo não é uma espécie humana radicalmente distinta da natureza. Se há um antropocentrismo, no perspectivismo tem a ver com a ideia de que a posição de sujeito é equivalente à ocupada por uma humanidade como condição (VIVEIROS DE CASTRO, 2002, p. 356). A etnografia multiespécie pode trazer à luz tanto exemplos de formas de pessoalidade do tipo "não humanos são pessoas" (KOHN, 2007; NADASDY, 2007), como podem tratar de não humanos tidos como se fossem pessoas, a exemplo dos trabalhos de Almeida (2016); Lewgoy; Sordi (2012); Sautchuck (2017); Segata (2012). Ingold esclarece:

(...) no ocidente, ser uma pessoa é ser um ser humano. Os animais podem somente ser pessoas na medida em que alguns membros de nossa humanidade convivem com eles em íntimo contato como se fossem membros da família. (...) O segundo exemplo de comparar animais a pessoas concerne às fábulas infantis. (INGOLD, 2000, p. 91).

Os pets (HARAWAY, 2003) podem ser considerados por seus donos "como se fossem pessoas"12, bem como os peixes para os pescadores (SILVA, 1988; CATÃO; BARBOSA, 2018) e as onças para os "mateiros" (SÜSSEKIND, 2014), porque a esses não humanos são atribuídas qualidades humanas. Já Ingold, Kohn e Nadasdy, e biólogos, como Kull, guardadas distinções teóricas entre eles, sustentam que os animais "são pessoas" por modificarem a acepção do conceito, como visto. O que diferencia o "animal que é uma pessoa" do "animal que é como se fosse uma pessoa" é que o primeiro surge em contextos onde o Grande Divisor não opera, a exemplo dos povos ameríndios, ou, em contexto em que está sendo questionado, como ocorre entre cientistas, sociais e naturais, que se esforçam para questionar o tipo de antropocentrismo inerente à dicotomia natureza/cultura,

\footnotetext{
${ }^{12}$ Não é raro adestradores de pets partirem do princípio que os gatos veem seus donos como gatos, assim como os cachorros os veem como cachorros. Para esses profissionais, então, a "perspectiva" dos pets consiste na atribuição de uma não-humanidade aos seus amos humanos.
} 
com a supremacia da racionalidade (científica).

É a intenção de trabalhar a ideia de uma natureza menos desvitalizada e menos neodarwinista uma importante diferença que existe entre etnografias mais recentes e a, por exemplo, de Evans-Pritchard (1978), sobre os Nuer, publicada pela primeira vez em 1940, e um dos mais fundamentais trabalhos etnográficos da antropologia. O primeiro capítulo foi dedicado ao gado criado pelos Nuer, pois o autor percebeu a grande importância que esses animais tinham para seus "nativos", deixando claro para o leitor o profundo conhecimento que possuíam sobre seu rebanho, além de grande estima:

Um Nuer conhece os hábitos de todos os seus bois, como um deles muge de noite, como outro gosta de liderar o rebanho quando volta ao acampamento, e como outro joga a cabeça para trás mais do que o resto. Ele sabe quais as vacas que ficam inquietas durante a ordenha, quais criam problemas com seus bezerros, quais gostam de beber no caminho para o pasto, e assim por diante. Se for um jovem, conseguirá um menino para ir à frente de seu boi predileto (de cujas características o jovem recebe o nome) em torno do acampamento, de manhã, e salta e canta atrás dele; frequentemente, de noite ele caminha entre o gado tocando um sino e cantando os louvores de seus compatriotas, suas namoradas e seus bois. (EVANS-PRITCHARD, 1978, p. 47).

Mesmo que para os Nuer suas vacas "sejam pessoas" ou "sejam como se fossem pessoas" (o trabalho não objetivava especialmente o estudo da relação com os animais), essa dimensão se transforma em um aspecto da diversidade cultural, coerentemente com a visão de "natureza como algo externo à cultura". Naqueles trabalhos antropológicos, a pergunta central podia ser: o que a natureza significa para as sociedades? Agora, há uma reformulação da pergunta em direção à subjetividade dos participantes não humanos que tomam parte de um coletivo, num sentido comparável ao que ocorre na biologia, com a retomada da biossemiótica de Uexküll. A comparação possível reside, sobretudo, no fato de que se pode testemunhar um crescente interesse pela "subjetividade" dos não humanos, que, nesse caso, são vistos como se fossem pessoas (quase humanas), ou ainda, seu "mundo próprio", sua Umwelt, dada por sua perspectiva. Para os biólogos, eles podem ser mais do que a estrita expressão de seus genes, e, para os antropólogos, eles "ganham voz" nas etnografias, numa reação do ideal romântico (DUARTE, 2004) frente a um século de empobrecimento do mundo vivo levada a cabo pelo neodarwinismo. 


\section{Considerações Finais}

Busquei evidenciar que há hoje em dia a aproximação entre (alguns) biólogos e (muitos) antropólogos em pelo menos três questões: (1) mal-estar com relação ao Grande Divisor, (2) a ideia de que a natureza significa em si, o que vai de par com (3) o reconhecimento de que animais não humanos não sejam, pura e simplesmente, a expressão de seu genoma, podendo ser considerados, inclusive, em determinados contextos e a partir de certas teorias, pessoas.

A crítica de Ingold com relação às metáforas teleológicas dos geneticistas integra seu projeto de afirmar, em oposição ao neodarwinismo, uma teoria da vida, conforme podemos depreender de muitos de seus escritos. A meu ver, tais metáforas são perfeitas por manifestarem o caráter quimérico da expressão "seleção natural". Creio que os antropólogos têm, em parte, os meios de contribuírem para uma biologia menos mecanicista, através de etnografias inspiradas na biossemiótica e de etnografias multiespécies, oferecendo alternativas à visão cartesiana dos organismos.

Finalmente, na medida em que o neodarwinismo separa natureza e cultura, meio ambiente e indivíduo, organismo e genes, "civilizados" e "selvagens", sua crítica é fundamental para a superação do Grande Divisor. A tentativa dessa superação, que busca a recomposição (epistemológica e ontológica) da dualidade natureza/cultura, rompida pelo ideário racionalista, é também a busca pela "totalidade", inerente ao ideário romântico, tal como caracterizado por Duarte (2004).

\section{Referências}

ALMEIDA, Juliano Florczak.

(2016). Bom Jardim dos Santos. Plantas, religiosidades populares e seus fluxos em Guarani das Missões (RS). Porto Alegre: UFRGS Editora.

BERGSON, Henri.

(2015). A evolução criadora. São Paulo: Martins Fontes.
CATÃ0, Brisa; BARBOSA, Gabriel C.

(2008). “Botos, peixes e pescadores: sobre a pesca conjunta em Laguna (Santa Catarina, Brasil). Revista do Instituto de Estudos Brasileiros, $\mathrm{n}$. 69, abril, p. 205-225.

CANGUILHEM, Georges.

(2012). Estudos de História e de Filosofia das Ciências. Concernentes aos vivos e à vida. Editora Forense Universitária. 
CARVALHO, Marcos Castro.

(2016). Producing chimeras: lineages of rodents, laboratory scientists and the vicissitudes of animal experimentation. Vibrant, vol. 13, n. 2, p. 160-176.

DARWIN, Charles.

(2004a). A Origem das Espécies. Belo Horizonte: Editora Itatiaia.

(2004b). A Origem do Homem e a Seleção Sexual. Belo Horizonte: Editora Itatiaia.

DESCOLA, Philippe.

(2013). A antropologia da natureza de Philippe Descola. (entrevista). Revista TOPOI. Vol.14, n. 27, p. 492-514.

DUARTE, Luiz Fernando D.

(2004). A pulsão romântica e as Ciências Humanas no Ocidente. Revista Brasileira de Ciências Sociais, v. 19, n. 55, p 5-18.

EVANS-PRITCHARD, E.

(1978). Os Nuer. Rio: Zahar ed.

FONSECA, Claudia; GARRID0, Rodrigo.

(2018). Os limites do humano: restos humanos em um laboratório de genética forense. Interseções. v. 20 n. 1. P. $14-35$

FRANCIS, Richard.

(2011). Epigenetics. The Ultimate Mystery of Inheritance. N.Y., W. W. Norton \& Company.

GALE, Barry G.

(1982). Evolution Without Evidence. Charles Darwin and The Origin of Species. Albuquerque, New Mexico Press.

GEERTZ, Clifford.

(1978). 0 Crescimento da Cultura e a Evolução da Mente. In A Interpretação das Culturas. Rio: Zahar. p. 67-98.

GODFREY-SMITH, Peter.

(2009). Darwinian Populations and Natural Selection. New York, 0xford University Press.

GOULD, Stephen Jay.

(2007). Punctuated Equilibrium. Cambridge, Massachusetts, Belknap Harvard, Harvard University Press.
HARAWAY, Donna.

(2003). The companion species manifesto. Dogs, people, and significant otherness. Chicago: Prickly Paradigm Press.

INGOLD, Tim

(2006). Distinção entre Evolução e História. Antropolítica. Revista Contemporânea de Antropologia n 20. Niterói. EDUFF.

(2007). Introdução a 0 que é um animal? Antropolítica. Revista Contemporânea de Antropologia, n. 22. Niterói, EDUFF.

(1990). An Anthropologist looks at Biology. Man, New Series, vol 25, n 2, jun. p. 208-209.

(2000). The Perception of the environment. Essays on livelihood, dweeling and skill. London and NY: Routledge.

(2011). Estar vivo. Ensaios sobre movimento, conhecimento e descrição. Petrópolis: Editora Vozes.

(2013a). Making. Anthropology, Archaeology, art and architecture. London and NY: Routledge Press. p 61-73.

(2013b). Prospect. In: INGOLD, Tim; PALSSON, Gisli. Biossocial Becomings. Integrating Social and Biological Anthropology. Cambridge, Cambridge Un.Press, p. 1-21.

(2019a). Evolução e Vida Social. Petrópolis: Ed Vozes.

(2019b). Evolution without inheritance: steps to an ecology of learning. [to appear] In Learning Ecologies, Ronald Barnett and Norman Jackson. (eds) Abingdon, Routledge.

JABLONKA, Eva; LAMB, Marion.

(2010). Evolução em quatro dimensões. São Paulo: Companhia das Letras.

KIRKSEY, S. Eben; HELMREICH, Stefan.

(2010). The emergence of multispecies ethnography. Cultural Anthropology, vol. 25, n. 4, p. 545-576. 
KOHN, Eduardo.

(2007). How dogs dream: Amazonian natures and the politics of transspecies engagement. American Anthropologist, vol. 43, n.1, pp 3-24. DOI: 10.1525/ae.2007.34.1.3.

(2013). How Forests Think. Toward na Anthropology beyond the Humana. California, Un. California Press.

KULL, Kalevi et al.

(2004). Uexküll and the post-modern evolutionism. Sign Systems Studies, vol. 32. n.1/2.

(2009). Theses on Biosemiotics: Prolegomena to a Theoretical Biology. Biological Theory, vol. 4, n. 2, p. 167-73.

KULL, Kalevi.

(2014). Adaptative evolution without natural selection. The Linnean Society Biological Journal. n.112, p. 287-294.

LALAND, Kevin; 0 'BRIEN, Michael J.

(2010). Niche Construction Theory and Archaeology. Journal Archaeol Method Theory. Springer LLC DOI 10.1007/s10816-010-9096-6)

LATOUR, Bruno.

(1994). Jamais fomos modernos. Ensaio de Antropologia Simétrica. Coleção Trans. Rio: Editora 34.

(2000). Ciência em ação. Como seguir cientistas e engenheiros sociedade afora. São Paulo: Ed. Unesp.

(2002). Politiques de la nature. Comment faire entrer les sciences en démocratie. Pairs, La Découverte/Poche.

\section{LÉVI-STRAUSS, C.}

(1976a). Raça e História. In: Antropologia Estrutural II, Rio de Janeiro, Tempo Brasileiro, capítulo XVIII. p. 328-366.

(1976b). A Ciência do Concreto. In: O Pensamento Selvagem. São Paulo: Companhia Editora Nacional.
LEWGOY, Bernardo; SORDI, Caetano.

(2012). Devorando a carcaça: contracozinhas e dietas alternativas na alimentação animal. Anuário Antropológico. II, p. 159-175.

LEWONTIN, Richard.

(2001). Gene, Organism and Environment: A New Introduction. In OYAMA, Susan; GRIFFITHS, Paul; GRAY, Russell. (orgs). Cycles of Contingency. Developmental Systems and Evolution. Cambridge, Massachusetts Institute of Technology Press, p. 55-66.

LIMA, Tânia Stolze.

(1996). 0 dois e seu múltiplo: reflexões sobre o perspectivismo em uma cosmologia Tupi. MANA, v.2, n. 2, p. 21-47.

LUNA, Naara.

(2012). Pesquisas com células-tronco: um estudo de caso sobre a dinâmica de um segmento do campo científico. História, Ciências, SaúdeManguinhos (Impresso), v. 19, p. 49-70.

MANICA, Daniela Tonelli.

(2018). CeSaM, as células do sangue menstrual: gênero, tecnociência, terapia celular. Interseções Revista de Estudos Interdisciplinares. vol.2 0, p. 93-113.

MAUSS, Marcel.

(1974) Uma categoria do espírito humano: a noção de pessoa, a noção de eu" In Sociologia $e$ Antropologia. vol. 2. São Paulo: EPU e EDUSP.

MAYNARD SMITH, John.

(2000). The concept of Information in Biology. Philosophy of Science, vol. 67, $\mathrm{n}^{\circ} 2$ (junho) p. 177-194: Published by: The University of Chicago Press on behalf of the Philosophy of Science Association. Disponivel em:

<http://www.jstor.org/stable/188717 >. Acesso em: 12 nov. 2014, 07:20.

MONTEIRO, Marko.

(2009). Representações digitais e interação incorporada: um estudo etnográfico de práticas científicas de modelagem computacional. MANA vol. 15, n. 2, p. 529-556.

NADASDY, Paul.

(2007). The gift in the animal: The ontology of hunting and human-animal sociality". American 
Ethnologist. vol 43. n.1. p. 25-43 D0I: 10.1525/ae.2007.34.1.25.

NICOLOSI, G.; RUIVENKAMP, G.

(2012). The epigenetic turn Some notes about the epistemological change of perspective in biosciences Med Health Care and Philos. 15:309-319 DOI 10.1007/s11019-011-9342-z Published online: 20 August 2011 Springer Science+Business Media B.V. 2011.

NUCCI, Marina Fisher.

(2010). 0 sexo do cérebro. Uma análise sobre gênero e ciência. In: Secretaria de Políticas para as Mulheres. (0rg.). $6^{\circ}$ Prêmio Construindo a Igualdade de Gênero - Redações, artigos científicos e projetos pedagógicos premiados. Brasília: Presidência da República, Secretaria de Políticas para as Mulheres.

OYAMA, Susan.

(2000). Evolution's Eye. A Systems view of the biology-culture divide. Durham e Londres: Duke University Press.

OYAMA, Susan; GRIFFITHS, Paul; GRAY, Russell.

(2001). Introduction: What is Developmental Systems Theory. In: OYAMA, Susan; GRIFFITHS, Paul; GRAY, Russell. (orgs). Cycles of Contingency. Developmental Systems and Evolution. Cambridge, Massachusetts Institute of Technology Press.

POPPER, Karl.

(1975). Conhecimento objetivo. Uma abordagem evolucionária. S. Paulo: Ed. Universidade de São Paulo e Ed. Itatiaia.

\section{SÁ, Guilherme.}

(2010). Abraços de mono: elos perdidos e encontros intersubjetivos em etnografia com primatólogos no Brasil. MANA. vol. 16, n. 1, p. 179-211.

SAUTCHUK, Carlos Emanuel.

(2017). Matar e Manter conservação ambiental como transformação técnica. Sautchuk Carlos Emanuel. (org) Técnica e transformação. Perspectivas antropológicas, Rio de Janeiro: ABA Publicações.
SEGATA, Jean.

(2012). Os cães com depressão e os seus humanos de estimação. Anuário Antropológico, II, p. 177204.

SILVA, Gláucia.

(1988). Tudo que tem na terra tem no mar. Rio, FUNARTE.

(1993). 0 que é Sociobiologia. São Paulo: Editora Brasiliense.

(2006). “A Sociobiologia e a crítica dos antropólogos". ComCiência. Revista Eletrônica de Jornalismo Científico, 8:3.

(2012). “Os antropólogos devem, sim, falar de biologia: a contribuição de Tim Ingold para uma reflexão sobre o darwinismo hoje". In: Steil, Carlos e Carvalho, Isabel (orgs). Cultura, percepção e ambiente. A contribuição de Tim Ingold para uma mudança de paradigma. São Paulo, Ed. Terceiro Nome. pp. 121-136.

(2017). Is natural selection a chimera? Reflections on the 'survival' of a principle. Vibrant.

SILVA, Gláucia e DUARTE, Luiz Fernando Dias.

(2016). Epigênese e epigenética: as muitas vidas do vitalismo ocidental. Horizontes Antropológicos.

SPENCER, Herbert.

(1893). The inadequacy of Natural Selection. Contemporary Review. n. 63, p.153-166.

STENGERS, Isabelle.

(2002). A invenção das ciências modernas. S. Paulo: Editora 34.

SÜSSEKIND, Felipe.

(2014). O rastro da onça. Relações entre humanos e animais no Pantanal. Rio: 7 Letras.

TSING, Anna.

(2015) Margens Indomáveis: Cogumelos como espécies companheiras.

DOI:http://dx.doi.org/10.5007/2175-

8034.2015v1n1p117. 
UEXKÜLL, Jakob Von.

(1982). The Theory of Meaning. Semiotica. vol. 42, n. I, p. 25-82.

(2008). Dos animais e dos homens. Digressões pelos seus próprios mundos. Doutrina e Significado. Lisboa: Editora Livros do Brasil.

VASSALLO, Simone.

(2018). Entre objetos da ciência e vítimas de um holocausto negro: humanização, agência e tensões classificatórias em torno das ossadas do sítio arqueológico Cemitério dos Pretos Novos. Interseções. v. 20, n.1, p. 36-66. D0I: 10.12957/irei.2018.35858

VIEIRA, António Bracinha.

(2009). A Evolução dos Darwinismo. Rio de Janeiro: Vieira \& Lent.
VIVEIROS DE CASTRO, Eduardo.

(2002). A Inconstância da Alma Selvagem e Outros Ensaios de Antropologia. São Paulo: Cosac \& Naify. 552 pp.

(2015). Metafísicas canibais: Elementos para uma antropologia pós-estrutural. S. Paulo: Cosac \& Naiif.

\section{Recebido em}

fevereiro de 2020

Aprovado em

julho de 2020 